\title{
Sharia Fintech as a Sharia Compliance Solution in the Optimization of Electronic-Based Mosque's Ziswaf Management
}

\author{
Umi Khaerah Pati", Pujiyono**, Pranoto*** \\ DOI: https://doi.org/10.22304/pjih.v8n1.a3
}

Submitted: October 17, 2020 | Accepted: March 17, 2021

\begin{abstract}
Research data from the Center for Strategic Studies of Baznas on Zakat Mapping Potential Indicators (IPPZ), which analyzes the calculation of zakat potential based on sectoral and regional zakat objects, shows that Indonesia has the potential for zakat of IDR 233.8 trillion in 2019. However, only 3.5 percent of them can be managed. Therefore, Baznas has collaborated with fintech but it is not yet based on sharia. This study uses the Islamic Economic Research Method (Muamalah) with a descriptive normative approach. The results showed that the digitalization of ZISWAF through fintech was effective and the results exceeded the target. On the other hand, according to some scholars, several forms of fintech operations contain non-Islamic elements. Therefore, the Baznas agreement must explicitly state that fintech should separate ZISWAF funds from other fintech user funds so that they are not considered as float funds to be placed in $\mathrm{BI}$; and do not utilize ZISWAF funds. Neither Baznas, muzakki, nor mustahik can benefit from depositing funds. Sharia fintech is a practical solution for UPZ Masjid to increase zakat inclusion. Unfortunately, Indonesia has no regulations related to sharia fintech.
\end{abstract}

Keywords: baznas, Islamic fintech, mosque's ziswaf.

\section{Fintech Syariah sebagai Solusi Kepatuhan Syariah dalam Pengoptimalan Pengelolaan Ziswaf Masjid Berbasis Elektronik}

\begin{abstract}
Abstrak
Data penelitian Pusat Kajian Strategi Baznas tentang Indikator Potensi Pemetaan Zakat (IPPZ) yang menganalisis perhitungan potensi zakat berdasarkan objek zakat sektoral maupun regional menunjukan bahwa Indonesia memiliki potensi zakat mencapai nilai Rp233.8 Triliun pada tahun 2019 namun hanya 3,5 persen yang dapat dikelola, oleh karenanya Baznas telah melakukan kerjasama dengan fintech namun belum berbasis syariah. Penelitian ini menggunakan Metode Penelitian Ekonomi Islam (Muamalah) dengan pendekatan deskriptif normatif. Hasil penelitian menunjukkan bahwa digitalisasi ZISWAF melalui fintech berjalan efektif dengan hasil penghimpunan melampaui target namun menurut sebagian ulama, beberapa bentuk operasional fintech mengandung unsur yang

PADJADJARAN Journal of Law Vol. 8 Number 1 Year 2021 [ISSN 2460-1543] [ISSN 2442-9325]

* Lecturer of Civil Law, the Faculty of Law, Universitas Sebelas Maret, Kentingan, Jl. Ir Sutami No. 36A, S.H., M.H. (Universitas Sebelas Maret), Umi_khaerah@staff.uns.ac.id

** Lecturer of Civil Law, the Faculty of Law, Universitas Sebelas Maret, Kentingan, Jl. Ir Sutami No. 36A, Prof. Dr. S.H., M.H. (Universitas Sebelas Maret), pujifhuns@staff.uns.ac.id

*** Lecturer of Civil Law, the Faculty of Law, Universitas Sebelas Maret, Kentingan, Jl. Ir Sutami No. 36A, S.H., M.H. (Universitas Sebelas Maret), Pranoto@staff.uns.ac.id
\end{abstract}


melanggar prinsip syariah, oleh karenanya, dalam perjanjian Baznas harus secara tegas menyebutkan agar fintech memisahkan dana ZISWAF dengan dana pengguna fintech lain sehingga tidak dipertimbangkan sebagai dana float yang akan ditempatkan pada Bl, tidak mendayagunakan dana ZISWAF, serta baik Baznas, muzakki maupun mustahik tidak mengambil keuntungan dari pendepositan dana, Fintech Syariah merupakan solusi praktis bagi UPZ Masjid agar dapat meningkatkan inklusi zakat, namun di Indonesia belum ada regulasi terkait fintech syariah.

Kata Kunci: baznas, fintech syariah, ziswaf masjid.

\section{A. Introduction}

The large number of Muslims in a country provides opportunities for welfare and economic equality through the collection of Zakat. Based on the 2020 World Population Review, Indonesia is the country with the largest Muslim population in the world. The following table shows the data of the 10 countries with the largest Muslim population in the world in 2020.

Table 1. Muslim Population in 2020

\begin{tabular}{|l|l|l|l|l|l|}
\hline No. & Country & \multicolumn{1}{|c|}{$\begin{array}{c}\text { Muslim } \\
\text { Population }\end{array}$} & $\begin{array}{c}\text { Population } \\
\mathbf{2 0 2 0}\end{array}$ & $\begin{array}{c}\text { Total } \\
\text { Population of } \\
\text { Muslim in the } \\
\text { Country (\%) }\end{array}$ & $\begin{array}{c}\text { Total } \\
\text { Population of } \\
\text { Muslim in the } \\
\text { World (\%) }\end{array}$ \\
\hline 1. & Indonesia & $229,000,000$ & $273,523,615$ & $87.20 \%$ & $12.70 \%$ \\
\hline 2. & Pakistan & $200,400,000$ & $220,892,340$ & $96.50 \%$ & $11.10 \%$ \\
\hline 3. & India & $195,000,000$ & $1,380,004,385$ & $14.20 \%$ & $10.90 \%$ \\
\hline 4. & Bangladesh & $153,700,000$ & $164,689,383$ & $90.40 \%$ & $9.20 \%$ \\
\hline 5. & Nigeria & $99,000,000$ & $206,139,589$ & $49.60 \%$ & $5.30 \%$ \\
\hline 6. & Egypt & $87,500,000$ & $102,334,404$ & $92.35 \%$ & $4.90 \%$ \\
\hline 7. & Iran & $82,500,000$ & $83,992,949$ & $99.40 \%$ & $4.60 \%$ \\
\hline 8. & Turkey & $79,850,000$ & $84,339,067$ & $99.20 \%$ & $4.60 \%$ \\
\hline 9. & Algeria & $41,240,913$ & $43,851,044$ & $99.00 \%$ & $2.70 \%$ \\
\hline 10. & Sudan & $39,585,777$ & $43,849,260$ & $97.00 \%$ & $1.90 \%$ \\
\hline
\end{tabular}

Zakat is obligatory for Muslims who have met the requirements. The Holy Quran, Chapter Al Baqarah verse 110 reads, "Establish prayer, and pay alms-tax. Whatever good you send forth for yourselves, you will 'certainly' find 'its reward' with Allah". Indonesia has the potential to collect optimal zakat funds but in fact based on data from the 2019 National Zakat Agency Report data on the collection of ZISWAF funds by the institutional Zakat Management Organization (OPZ) is still minimal according to the 2019 National Amil Zakat Agency Report. ${ }^{1}$

1 Badan Amil Zakat Nasional, "Laporan Statistik Badan Amil Zakat Nasional Tahun 2019", https://baznas.go.id/szn/2019, accessed on October 2020. 
Table 2. Data on OPZ Collection by Type of Fund

\begin{tabular}{|c|c|c|c|c|c|}
\hline No. & $\begin{array}{c}\text { Type of LAZ } \\
\text { Data }\end{array}$ & National LAZ & Provincial LAZ & $\begin{array}{c}\text { City/Regency } \\
\text { LAZ }\end{array}$ & $\begin{array}{c}\text { OPZ in } \\
\text { Institution }\end{array}$ \\
\hline 1. & $\begin{array}{l}\text { Zakat Maal } \\
\text { of Income }\end{array}$ & $\begin{array}{l}903,719,092,6 \\
19\end{array}$ & $\begin{array}{l}60,514,993,34 \\
3\end{array}$ & $\begin{array}{l}64,347,661,68 \\
9\end{array}$ & $\begin{array}{l}309,877,627,4 \\
35\end{array}$ \\
\hline 2. & $\begin{array}{l}\text { Zakat Maal } \\
\text { Agency } \\
\text { (Zakat Maal } \\
\text { Organization) }\end{array}$ & $\begin{array}{l}86,649,310,72 \\
6\end{array}$ & $680,698,539$ & $1,816,552,859$ & 0 \\
\hline 3. & Zakat Fitrah & $\begin{array}{l}40,790,462,74 \\
3\end{array}$ & $5,800,483,003$ & $7,220,742,237$ & 0 \\
\hline 4. & $\begin{array}{l}\text { Infak/ } \\
\text { Sadaqah } \\
\text { (Destined) }\end{array}$ & $\begin{array}{l}559,472,597,5 \\
00\end{array}$ & $\begin{array}{l}155,051,363,4 \\
20\end{array}$ & $\begin{array}{l}148,840,376,5 \\
23\end{array}$ & 0 \\
\hline 5. & $\begin{array}{l}\text { Infak/ } \\
\text { Sadaqah } \\
\text { (Undestined) }\end{array}$ & $\begin{array}{l}905,989,382,9 \\
05\end{array}$ & $\begin{array}{l}78,897,295,24 \\
4\end{array}$ & $\begin{array}{l}37,886,536,65 \\
7\end{array}$ & $\begin{array}{l}64,175,229,49 \\
5\end{array}$ \\
\hline 6. & CSR & $\begin{array}{l}92,466,587,67 \\
4\end{array}$ & $5,739,069,236$ & $4,382,477,903$ & 0 \\
\hline 7. & $\begin{array}{l}\text { Other } \\
\text { Religious } \\
\text { Social Funds }\end{array}$ & $\begin{array}{l}407,074,806,9 \\
59\end{array}$ & $\begin{array}{l}37,046,454,04 \\
9\end{array}$ & $\begin{array}{l}29,945,673,55 \\
5\end{array}$ & $\begin{array}{l}178,927,143,0 \\
70\end{array}$ \\
\hline & Total & $\begin{array}{l}2,996,162,241 \\
, 125\end{array}$ & $\begin{array}{l}343,730,356,8 \\
34\end{array}$ & $\begin{array}{l}294,440,021,4 \\
23\end{array}$ & $\begin{array}{l}552,980,000,0 \\
00\end{array}$ \\
\hline
\end{tabular}

In addition, the Puskas Baznas explains the Potential Indicators for Zakat Mapping (IPPZ). It analyzes the calculation of the potential for sectoral and regional zakat in Indonesia, which is based on five factors. The factors are agricultural, companies, zakat on livestock, potential for income zakat, and deposits. The data shows that Indonesia has the potential for zakat up to Rp233.8 trillion in 2019. However, only 3.5 percent can be managed. ${ }^{2}$ In addition, since the Covid-19 pandemic, the lockdown has restricted people from visiting mosques for any purposes, including to pray. Baznas has made efforts to optimize the digitalization of ZISWAF through various collaborations with the fintech payment gateways, e-commerces, and crowdfunding in Indonesia such as Ovo, Gojek, Shopee, and others to raise funds by depositing rupiah currency into the e-wallet platform. The managers of ZISWAF

\footnotetext{
2 Pusat Kajian Strategis Badan Amil Zakat Nasional, Outlook Zakat Indonesia 2020, Jakarta: Pusat Kajian Strategis - Badan Amil Zakat Nasional (PUSKAS BAZNAS), 2020, p. 26.
} 
mosques can follow up this cooperation by paying attention to the principles of sharia. The fintech operations in collaboration with Baznas are still subject to general legal rules and are not subject to sharia rules. For this reason, it is necessary to know further about the concept of digitalization of ZISWAF to optimize the collection of Zakat, Infaq, Sadaqah, and Waqf in Indonesia and to make sharia fintech as a solution to optimize the accumulation and distribution of mosques' ZISWAF.

\section{B. Mosque as Part of the Ziswaf Management Organization Structure in Indonesia}

At the beginning of the Islamic period, the management of zakat, infaq, sadaqah, and waqaf (hereinafter referred to as ZISWAF) was fully handled by the Islamic state through the construction of Baitul Maal. Prophet Muhammad (Peace be Upon Him) founded Baitul Maal in charge of collecting, managing and distributing zakat through an amil (a collector). ${ }^{3}$ The collection of zakat is mandatory for Muslims who have reached the minimum limit of zakat (nisab), in the sense that the property is perfect, exceeds basic needs, free from debt, and has reached its haul, i.e. the property has lasted more than one year. ${ }^{4}$

Quran and Hadith require officers who are devoted to managing zakat manage zakat. In Indonesia, the government forms a Zakat Management Organization (OPZ) based on the Law Number 23 of 2011 on Zakat Management in Indonesia in conjunction with the Government Regulation Number 14 of 2014 on the Implementation of the Law Number 23 of 2011 on Management of Zakat. OPZ consists of the National Amil Zakat Board (Baznas - Badan Amil Zakat, Infaq, dan Sadaqah) at the central, provincial, and regency or city level, the Amil Zakat Institution (LAZ - Lembaga Amil Zakat), the Zakat Management Unit (UPZ - Unit Pengelola Zakat), and individuals or groups of amil zakat in an area that have not been reached by the Baznas and the LAZ. The management of zakat management activities is carried out with a written notification to the Head of the District Office of Religious Affairs (KUA).

Baznas is a non-structural, independent government institution. It has an authority to manage zakat nationally and is accountable to the President through the Minister of Religious Affairs. Baznas has eleven members, consisting of eight members from elements of society (Islamic scholars, Islamic religious leaders, and professionals) and three members from government (appointed and dismissed by the President based on the recommendation from the Minister of Religious Affairs). Baznas members serve for five years and have the right to be re-elected for another one term of office. At the district and city level, the Provincial Governors

Ascarya and Diana Yumanita, "Analisis Rendahnya Pengumpulan Zakat di Indonesia dan Alternatif Solusinya", Working Paper Bank Indonesia, No. 9, 2018, p. 7.

4 Rudi Hermawan, Buku Ajar Hukum Ekonomi Islam, Pamekasan: Duta Media Publishing, 2017, pp. 28-30. 
and Regents or Mayors appoint the Baznas members with the consideration of the Central Baznas.

In carrying out its duties, Baznas can be assisted by Amil Zakat Institution (LAZ Lembaga Amil Zakat). It is community institution in charge of collecting, distributing, and utilizing zakat. LAZ on a provincial scale can only form one representative in each regency or city by submitting a written application to the Head of the District or City Religious Court Office.

In addition, Zakat Management Unit (UPZ - Unit Pengelola Zakat) also assists Baznas. It is an organizational unit formed by Baznas to collect zakat from state institutions, state-owned enterprises, national and foreign private companies, representatives of the Republic of Indonesia abroad, offices, colleges, schools/madrasahs and other educational institutions, mosques, prayer rooms, langgar, and surau. UPZ activities refer to the principles of zakat distribution and utilization.

Every mosque, langgar, surau, or musala in Indonesia can register or propose to become an UPZ. Two mechanisms can be taken. The first is the recommendation from by Baznas at provincial, regency, or city level to the institution supervising the UPZ candidate. The second is the proposal by the head of the UPZ candidate institution. The formation of UPZ through the Baznas proposal is carried out by submitting a written letter to the head of the institution to be formed. Within 30 days, the UPZ candidate leader must have given the answer. Proposals by the leadership of the UPZ institution/candidate are made by submitting a written submission to the provincial, regency, or city Baznas by attaching complete administrative requirements. Not later than five working days after the proposal is received Baznas is obliged to provide an answer to the proposal. After that, Baznas carries out administrative verification. If it has been verified, a decision to form the UPZ is determined and is endorsed by the head of Baznas at provincial, regency, or city levels.

The UPZ organization consists of administrators and advisors, which include at least chairperson, secretary, and treasurer from UPZ members or congregations. The duties of the management are to determine the Annual Work Plan and Budget. It is a document that contains the work program and work budget of the UPZ, conduct evaluations, compile a plan for collecting zakat, muzaki data management, education, and socialization of zakat, serving zakat consultation, and provide the results of the collection of zakat to Baznas. UPZ management is entitled to Amil certification training from Baznas in the context of skill development. The UPZ's Annual Work Plan and Budget is determined based on the considerations of the UPZ advisors from the head of the institution. Advisory functions provide consideration and supervision of UPZ in carrying out its duties and functions as well as assisting the management in procuring UPZ facilities and infrastructure. The 
length of office for UPZ members is five years and can be re-elected, appointed, and dismissed based on the decision of the chairman of Baznas.

\section{Financial Digitalization to Optimize Ziswaf Collection in Indonesia}

In the era of digital development, various types of innovations have emerged in the financial services sector. Digitalization in the financial sector is an effort to optimize the inclusion of financial services by minimizing various barriers to public access to the use of financial services. ${ }^{5}$ Financial inclusion is a global program to provide financial access to the wider community, especially the poor, productive poor, residents in disadvantaged areas, and immigrant workers so they can access financial services anywhere and anytime. ${ }^{6}$ The financial inclusion strategy is described in the Presidential Regulation Number 82 of 2016 on the National Strategy for Financial Inclusion, which divides it into five pillars. They are the pillars of financial education, community property rights, intermediation facilities, and financial distribution channels, financial services in the government sector, and the pillars of consumer protection. ${ }^{7}$ Both $\mathrm{OJK}$ and $\mathrm{BI}$ have synergized in efforts to implement these five pillars. The details of these five pillars are as follows.

1. Financial education and literacy aim to increase public knowledge and awareness regarding financial service products that include features, benefits, risks, costs, as well as rights and obligations. The OJK realizes this strategy through its sub-division for financial education implementation by conducting regular surveys in 34 provinces and 67 cities/regencies. ${ }^{8}$ The Bank Indonesia, on March 30, 2020, released the Islamic economic literacy index, which is an indicator of the level of literacy of the Indonesian people towards the Islamic economy and the level of public inclusion in Islamic financial services, particularly Islamic social finance (Ziswaf).

2. The pillar of community property rights aims to increase public affordability in accessing credit at formal financial institutions. To implement this pillar, the OJK develops a peer-to-peer landing financial technology financing model. Interest on borrowing costs is regulated by the Indonesian Joint Funding Fintech Association (AFPI - Asosiasi Fintech Pendanaan Bersama Indonesia). The total loan cost does not exceed a flat interest rate of $0.8 \%$ per day. There is also a stipulation that the total amount of fees, postage fees, and all other fees is a maximum of $100 \%$ of the principal value of the loan. All operators registered/licensed at the OJK must follow this provision.

\footnotetext{
Departemen Pengembangan Akses Keuangan and UMKM Bank Indonesia, Booklet Keuangan Inklusif, Jakarta: Bank Indonesia, 2014, p. 2.

$6 \quad$ Evi Steelyana W, "Perempuan dan Perbankan: Sebuah Tinjauan tentang Inklusi Keuangan terhadap Pengusaha UMKM Perempuan di Indonesia (Woman and Banking: A Review of the Role of Financial Inclusion on Woman SME Enterpreuners in Indonesia)", Economics, Business and Information System Journals, Vol. 14, No. 2, 2013.

7 Departemen Pengembangan Akses Keuangan and UMKM Bank Indonesia, op.cit., p. 4.

8 Otoritas Jasa Keuangan, "Siaran Pers Survei OJK 2019 tentang Indeks Literasi dan Inklusi Keuangan Meningkat, https://www.ojk.go.id/id/berita, accessed on November 2020.
} 
3. The pillar of intermediation facilities and financial distribution channels aims to expand public financial access. To implement this pillar, the OJK has synergized with the Bank Indonesia to form a policy of fintech peer-to-peer landing, equity crowdfunding, and payment. ${ }^{9}$ The Bank Indonesia becomes a facilitator in terms of providing land for payment traffic.

4. Pillar of financial services in the government sector aims to improve governance and transparency of public services in the distribution of non-cash government funds. Information asymmetry is a common problem faced by the public when transacting with financial service businesses, including fintech. Problems that usually arise are the existence of products with prices and payment terms that confuse consumers. There are "hidden fees and charges" that are not understood; and there is no disclosure of information on the operational implementation of kaffah Islamic financial institutions and other various conditions. The OJK and the Bank Indonesia are obliged to encourage fintech providers to explain in detail content, product format, risks, and rights and obligations of parties to consumers as outlined in an agreement based on transparency and information disclosure. They should take into account the OJK Regulation Number 1/POJK.07/2013 on Protection for Consumer of Financial Services Sector (POJK Consumer Protection). The organizers report the implementation of these provisions annually through an independent assessment to the OJK. For public services related to complaints or protests about the lack of transparency in the operations of financial institutions, the OJK and the $\mathrm{BI}$ provide a public complaint page at https://konsumen.ojk.go.id/FormPenguhan (OJK) and https://www.bi.go.id/id/edukasi-perlindungan-konsumen (BI). Therefore, the lack of transparency will be immediately followed up by OJK and $\mathrm{BI}$ and evaluated by the organizers of the financial institution.

5. The pillar of consumer protection is implemented based on several provisions. They are, among others, the Regulation of the Minister of Communication and Information Number 20 of 2016 on Personal Data Protection in Electronic Systems, Article 31 the OJK Regulation Number 13/POJK.02/2018 on Digital Financial Innovation in the Financial Services Sector. The organizers are required to apply basic principles of consumer protection, namely transparency, fair treatment, reliability, confidentiality, and security of consumer data/information. On the other hand, consumer protection for fintech payments is regulated in the Regulation of the Bank Indonesia Number 19/12/Pbi/2017 on the Implementation of Financial Technology. The Bank

9 Otoritas Jasa Keuangan, "7 Inisiatif Strategis OJK untuk Pertumbuhan dan Pemerataan Ekonomi", https://www.ojk.go.id/id/berita-dan-kegiatan, accessed on November 2020. 
Indonesia regulates the implementation of financial technology to apply consumer protection principles as well as risk and prudential management. In addition, Bank Indonesia also ensures protection of consumers, especially regarding the guarantee of confidentiality of consumer data and information through cybersecurity networks.

The OJK categorizes fintech as the non-bank financial industry (IKNB). It is an innovation to increase financial inclusion in developing and developed countries. ${ }^{10}$ The presence of fintech can provide solutions to the problem of Islamic financial inclusion based on the results of a 2016 survey conducted by the OJK). It reveals that, although the majority of Indonesians are Muslim, the level of literacy and financial inclusion in sharia is still very minimal. ${ }^{11}$ Some experts argue that the accessibility dimension greatly affects the Islamic financial inclusion index in Indonesia. ${ }^{12}$

The use of fintech as a support for state financial inclusion can be implemented in the concept of collecting and distributing Ziswaf funds. Previously, Baznas have developed the use of technology in Ziswaf transactions such as establishing Android-based digitization of zakat through the Baznas application, LAZ Muhammadiyah (LAZMU), LAZ Initiative Zakat (LAZIZ), and the Muzaki Corner Baznas application. However, along with the development of technology, an innovation known as fintech (financial technology) emerged and became a trend and was in great demand in 2010. This has prompted Baznas to collaborate. Fintech is a financial service product developed by an online non-bank, non-insurance company that offers alternative ways to access a variety of financial services, from money transfers to financial planning. ${ }^{13}$

Fintech is generally a start-up company in the micro, small category that the number continues to increase. ${ }^{14}$ In Indonesia, the operations is subject to the regulations of the OJK, specifically for fintech peer to peer lending and equity crowdfunding and Bank Indonesia regulations for fintech payment systems. The legal basis for the formation of fintech in Indonesia includes the Regulation of Bank Indonesia Number 18/40/PBI/2016 on the Implementation of Payment Transaction Processing, the Circular of Bank Indonesia Number 18/22/DKSP on the Implementation of Digital Financial Services, the Regulation of Bank Indonesia Number No. 20/06/PBI/2018 on Electronic Money, the Regulation of the Financial

10 Peterson K. Ozili, "Impact of Digital Finance on Financial Inclusion and Stability", Borsa Istanbul Review, Vol 18, No. 4, 2018, p. 339.

11 Azwar Iskandar, "Index of Syariah Financial Inclusion in Indonesia (Indeks Inklusifitas Keuangan Syariah di Indonesia)", Jurnal Buletin Ekonomi Moneter dan Perbankan, Vol. 20, No. 1, 2017, p. 102.

12 I Made Sanjaya and Nursechafia, "Keuangan inklusif dan Pertumbuhan Inklusif: Analisis antar Provinsi di Indonesia", Buletin Ekonomi Moneter dan Perbankan, Vol. 18, No. 3, 2016, p. 304.

13 Imran Gulamhuseinwala, Thomas Bull and Steven Lewis, "Fintech is Gaining Traction and Young, High-Income Users are the Early Adopters", Journal Of Financial Perspectives, Vol. 3, Issue 3, 2015.

14 Svetlana Saksonova and Irina Kuzmina-Merlino, "Fintech as Financial Innovation - The Possibilities and Problems of Implementation", European Research Studies Journal, Volume XX, Issue 3A, 2017, p. 962. 
Services Authority of the Republic of Indonesia 77/POJK.01/2016 on the Information Technology-Based Borrowing and Lending Services, and the Regulation of the Financial Services Authority of the Republic of Indonesia Number 13/Pojk.02/2018 on Digital Financial Innovation in the Sector Financial Services.

The types of fintech that can be used to redeem Ziswaf are fintech payments, wallets, and crowdfunding donations in collaboration with Baznas. The fintech payments, wallets, and crowdfunding donations can provide zakat payment menus, for example on the Shoppe application, people can pay Ziswaf on the Laznas Griya Yatim and Duafa menu; on the Go-pay application (fintech payment) people can pay Ziswaf through the Go-Give menu; and on the KitaBisa application (fintech donation crowdfunding), which was specially formed to pay Ziswaf and donations.

Currently Baznas has collaborated with popular fintechs in Indonesia with payment gateway platforms, e-commerce, and crowdfunding donations. They are Tokopedia, Go-Pay, Go-Give, OVO, KitaBisa, SOBATKu, Lenna, Muslim Tourism, Asuransi Jasinda Syariah, Muzaki Camer, Electronic Commerce, Elevania, Blibli, Shopee, Lazada, Matahari Mall, JD.ID, Bukalapak, Internet Banking, SMS Banking, EDC, Mandiri E-Cash, Daku Wallet, BRI E-Pay, T-Cash, etc. ${ }^{15}$ The effectiveness of the use of digital zakat can be seen from the results of a Baznas survey in 2019, which recorded 42,030 muzaki distributing Ziswaf with 75,471 transactions via digital platforms with collection results that exceeded the target. This is because there are so many users and enthusiasts of fintech. For instance, approximately 155 million users have downloaded the Gojek application, on semester 1 of $2019 .{ }^{16}$ Millions of Go-jek users can easily donate to Ziswaf through the donation service on the GoGive platform via the Go-Pay payment method. The validity of the online or digital zakat contract, according to the opinion of the scholars, is permissible while ensuring that the distribution of zakat is transparent and on target. ${ }^{17}$

Baznas collaborative activities with other parties have been regulated in the Regulation of the National Zakat Agency of the Republic of Indonesia Number 6 of 2018 on Guidelines for Implementation of Cooperation in the Zakat Management Environment. The Baznas Regulation explains that in carrying out cooperation within the scope of zakat management, Baznas must be guided by the following principles.

1. OPZ is obliged to comply with sharia principles, in the sense that every implementation of cooperation.

\footnotetext{
Pusat Kajian Strategis Badan Amil Zakat Nasional, op.cit.

16 Eldo Christoffel Rafael, "Alvara Research Center: Go-Jek jadi Terfavorit di Kalangan Milenial”, https://industri.kontan.co.id/news/alvara-research-center-go-jek-jadi-terfavorit-di-kalangan-milenial, accessed on October 2020.

17 Badan Amil Zakat Nasional, "BAZNAS Ajak Masyarakat Zakat Digital", https://baznas.go.id/Press_Release/baca/BAZNAS_Ajak_Masyarakat_Zakat_Digital/531, accessed on October 2020.
} 
2. Cooperation is free from elements of maisir (gambling), gharar (speculative), haram and riba (usury), or vanity interests.

3. They provide benefits and mutual benefits among the parties and support the effectiveness of zakat management.

4. Every cooperation is carried out in a measured and reported manner in accordance with the relevant regulations.

The operational implementation of several fintech payments in collaboration with Baznas (such as Gojek, OVO, Shopee, and Sobatku) carry out several activities. For some scholars, some activities are against sharia principles because they have the potential to generate usury for service users. For example, Gojek, Ovo, Shopee provide electronic wallet services (Go-Pay, E-Shopee, and Ovo) to facilitate consumers to deposit funds through transfers to their accounts (called top-up). Service users can use money that has been deposited to debit every transaction at any time. The funds that have been top-up cannot be withdrawn again.

Electronic service providers can use funds deposited in electronic wallets to invest in other types of businesses without supervision from the sharia authorities. The results of using top up funds for investment provide benefits for service users in the form of discounts or Go-Pay or Shopee vouchers. The use of discounts or vouchers, referring to the opinion of some scholars, is haram because they contain usury. Some opinions regarding whether or not the use of Go-Pay vis-a-vis e-wallet are as follows.

1. Some scholars, one of them Dr. Firanda Andirja, M.A., ${ }^{18}$ state that transactions in Gojek were categorized as a qard contract because the money deposited in the Go-Pay account was actually borrowed. Go-Jek could use the money for other investments. Discounts or vouchers given to service users are considered additional (usury), based on the service users's money. This study is of position to agree with Dr. Firanda Andirja, MA. Although the funds that are topped up on Go-Pay are in the form of savings/deposits, the money stored is essentially consumables. The money can be invested by Go-Jek and even required by BI to be placed in Bl's securities and national securities with interest rates. Go-Jek is only charged with the obligation to return it when the user needs it. Depositing transactions are lawful but Go-Jek's actions to invest funds in securities in exchange for interest violate sharia principles. Therefore, it is feared that there will be a mixture of Ziswaf funds with interest returns.

2. There is a multi-contract activity on one of the Go-Jek platforms. According to some scholars, it combines the ijarah (lease) and qard (debt and credit)

18 Firdos Nofrison, "Studi Analisis terhadap Fatwa Dewan Fatwa Perhimpunan Al-Irsyad No: 005/Dfpa/Vi/1439 tentang Haramnya Diskon yang Didapatkan dari Go-Pay dan Layanan yang Sejenisnya", Skripsi, UIN Suska Riau, 2019, p. 7. 
contracts, ${ }^{19}$ namely combining an ojek service agreement and a Go-Jek loan money contract to pay for food at use of the Go-Food platform. Multi-contract (murakkab) is an agreement between two or more people to perform a contract by combining two or more contracts such as combining a sale and purchase contract with ijarah (lease), qard (debt-receivables), wakalah (power of attorney), syirkah (cooperation), etc. Therefore, all legal consequences, both rights and obligations, that arise cannot be separated because they are considered as a unit as a legal consequence of one contract. ${ }^{20}$ According to the hadith from Amr ibn Syu'aib, "There are two conditions in buying and selling and not buying and selling (combined) with a loan." Then, the hadith from Amr ibn Syu'aib, "It is not lawful to buy and sell loans." The Hadith from Abdullah ibn Amr ibnu al-Ash reads, "Two conditions are not allowed in a sale and purchase and cannot combine buying and selling with loans". ${ }^{21}$ This study is of position to agree that there are multi-contracts in the Go-Food transaction but not the merger between the qard and ijarah contracts, as the scholars' opinion above, but combines the ijarah and wakalah contracts. After the user agrees to buy the food shown in the Go-Food catalog, an inter-service contract (ijarah) appears and is combined with the wakalah bil ujrah contract, which is a contract of sale and purchase on behalf of the driver to buy it first in exchange for a fee (ujrah). The benefits obtained by the driver are fees for inter-service administrations that are administered by the Go-Jek company. However, the author also agrees with the opinion of Ammi Nur Baits, from the Syari'ah Consultation Board, that there is a need for a more in-depth examination of the Go-Food transaction process, even though the Go-Jek transaction indicates multiple contracts..$^{22}$ In addition to scholars who prohibit them, some scholars argue that the Go-Food sale and purchase agreement is valid and may be due to the transactions that occur in Go-Food, the parties both know each other and understand, including the issue of goods prices and shipping costs. The rule used is "in principle, the agreement is seen from its intention and meaning, and not on the pronunciation and shape ${ }^{\prime 23}$ In this case, the view of the scholars pays more attention to the principle of agreement, or pleasure as stated in the Holy Quran, Chapter Annisa, verse 29 that in muamalah transactions, the willingness or pleasure of both parties is mandatory.

9 Muhammad Abdul Wahab, Lc, "Benarkah Go-Food Haram?", https://www.rumahfiqih.com/, accessed on October 2020.

2 Nazih Hammad, Al-Uqud Al-Murakkabah fi Al-Fiqh Al-Islamiy, Damaskus: Dar al-Qalam, 2005, p. 7.

1 HR Ibnu Hibban and Abd ar-Razzaq.

22 Ahmad Syahid, "Go-Food dalam Tinjauan Cendekiawan Muslim", FINANSIA: Jurnal Akuntansi dan Perbankan Syariah, Vol. 1, No. 1, 2018, p. 115.

23 Ahmad Syahid, op.cit., p. 116. 
In addition to the opinions of the scholars, Baznas is also working with Sobatku, a start-up that provides online products/savings (fintech wallet). However, in the Sobatku transaction, there are elements that violate sharia principles. In order to attract the public, every month and quarter, Sobatku holds a lottery with a total prize value of billions of rupiah and a grand prize with a grand prize of IDR 100 million plus four Umrah prize packages for four winners. In addition, there is also a monthly lottery with a minimum cash prize of IDR 100,000 to IDR 10 million. From the perspective of Islamic law, the lottery is haram if the conditions for participation in the lottery are required to buy goods or products that are determined by the organizer for profit or loss due to loss of balance. ${ }^{24}$ To be able to participate in the My Buddy lottery, users are required to have a My Buddy account with a minimum daily balance of IDR 50,000.00 in the month of the draw. Every first of month are users' points are renewed. ${ }^{25}$

In fintech operations, there is also no special authority institution to oversee fintech operations such as sharia banks that are supervised by the National Sharia Council of the Indonesian Ulema Council (DSN MUI) in operational matters, including the use of deposited customer funds to be invested in halal and toyyib activities only. In addition, depositing funds on the e-wallet platform is not guaranteed by the Deposit Insurance Corporation (LPS). The insurance coverage of LPS, which is stated in the Law Number 24 of 2004 on the Deposit Insurance Corporation, only guarantees customer deposits in banks in the form of savings, current accounts, deposits, certificates of deposit, and other similar forms. The bank is guaranteed by the LPS for the payment of claims by depositors at the bank whose business license has been revoked, resolves, and handles failed banks, and orders every bank conducting business in the territory of the Republic of Indonesia to become a participant of the guarantee. No institution is related to fintech, so the risk of losing funds deposited when a fintech company goes bankrupt is greater.

Indications of fintech transactions that violate sharia principles can also be seen in Article 48 of the Regulation of Bank Indonesia Number 20/6/PBI/2018 on Electronic Money, that all electronic money values residing in Issuers (fintech) result from refills or top ups which are an obligation. Issuers to Users and Providers of Goods and/or Services or known as float funds, are placed at least $30 \%$ (thirty percent) in demand deposits of commercial banks and at most $70 \%$ (seventy percent) are placed in securities issued by the Government or Bank Indonesia. The form of securities issued by the government or Bank Indonesia is in the form of bonds, so that the recipient of the bonds receives regular interest (usury).

Regardless of whether the operational form of fintech in collaboration with Baznas is haram or not, Islamic law recommends that in dealing with something

24 Dzulqorinain bin Muhammad Sunus, "Beberapa Hukum Berkaitan dengan Undian", https://darussalaf.or.id/beberapa-hukum-berkaitan-dengan-undian/, accessed on October 2020.

25 Simpanan Online Sahabatku, "Aturan Umum Pengguna Sobatku", https://www.sobatku.co.id/aturan-jadwalundian-sobatku, accessed on October 2020. 
that raises doubts it is best to abandon it. Hadith from Abu Muhammad Al-Hasan bin 'Ali bin Abi Thalib reads as follows.

"Leave everything that doubts you and take those that don't doubt you. Honesty will bring calm. Lies will bring anxiety."

Islam teaches to choose to leave those who doubt whether it is good or bad, halal or haram and choose those that do not doubt, those that are believed to be good and halal.

\section{Sharia Fintech as Baznas Solution to Optimize Ziswaf Collection and Distribution with Sharia Compliance}

The discovery of algebra, numeric, and basic science of algorithms in $830\left(9^{\text {th }}\right.$ Century BC) by Muhammad ibn Musa al-Khowarizmi, a scientist from Persia (currently Iran) ${ }^{26}$ are pillars of the development of modern technological discoveries. It has opened up opportunities for the emergence of various modern technologies. One of them is Al (artificial intelligence), which is a branch of computer science that includes algorithms, computation, logic and probability to form smart machines. The integration of artificial intelligence (AI) into financial technology resulted in fintech 3.0 in 2008 marked by the emergence of start-up companies that provide direct financial products and services to the public. ${ }^{27}$ Fintech provides financial intermediation services cheaper than the traditional way. It can attract and reach large numbers of consumers by reducing the costs of identifying, monitoring, and managing financial services risk. ${ }^{28} \mathrm{Al}$ enables fintech companies to analyze consumers, credit scoring, data-based trading, detect errors or fraud, etc. easier. ${ }^{29}$ Fintech focuses on the representation and process of the finance algorithm, which is a systemic procedure, used to specify financial communication protocols, legal compliance from competent authorities, clearing and placement of transactions, representing codes of financial information such as prices and orders, authentication, and describing selling-and-buying decision rules. Fintech integrates mathematics, statistics, computation, economic modeling, analysis systems that comply with laws, procedures, guidelines, regulations, strategy and tactics, logistics, information processing, confidentiality, resource allocation, and prediction of possible risk of loss. ${ }^{30}$

Islamic fintech or sharia fintech is a combination of technology and sharia finance in the sense that every product or service originating from fintech must

\footnotetext{
Roy S. Freedman, Introduction to Financial Technology, United States: Academic Press, 2006, p. 71.

27 Douglas W. Arner, Janos Nathan Barberis and Ross P. Buckley, "The Evolution of Fintech: A New Post-Crisis Paradigm?", University of New South Wales Law Research Series, p. 17.

28 Nafis Alam, Lokesh Gupta, Abdolhossein Zameni, Fintech and Islamic Finance: Digitalization, Development and Disruption, Switzerland: Springer Nature, 2019, p. 6.

29 Ibid, p. 3.

30 Roy S. Freedman, op.cit., p. 1.
} 
comply with the regulations that come from the Holly Quran and the Hadith. The sharia fintech platform takes advantage of technological revolutions such as $\mathrm{Al}$, blockchain, big data, extensive cloud computing, and the internet of things (IoT) to provide Islamic financial services in a more sophisticated and transparent form. Sharia fintech can provide broad access to sharia financial services at lower costs, an easier way of financing, payment and investment services while adhering to sharia principles. ${ }^{31}$ Even though Indonesia has not regulated regarding sharia fintech, sharia fintech has developed in various worlds, and some are even devoted to collecting and distributing Ziswaf.

At the global level, based on data from the 2019 Global Islamic Economic Report, sharia fintech is predicted to increase sharply with an asset value of approximately 3.5 trillion dollars. ${ }^{32}$ In 2018, the number of sharia fintechs in the world was $93^{33}$, and in 2020 it increased to 142 sharia fintechs. ${ }^{34}$ There are some world-renowned Islamic fintechs and some of which were specially formed to collect Ziswaf. First, EthisCrowd is the world's first Islamic real estate crowdfunding platform, investing in entrepreneurial, business, trading and real estate activities. It grows rapidly in Asia and is based in Singapore. This fintech raises funds for the construction of commercial homes through investors from public companies. Second, Adab Sollution is a sharia-based fintech remittance belonging to the United Arab Emirates that utilizes blockchain technology and cryptocurrency as virtual currencies to transfer money between countries. Third, Finterra and Global Sadaqah are sharia fintechs that provide a crowdfunding platform that can be accessed by Muslims around the world specifically to collect zakat, waqaf, sadaqah, and infaq globally by utilizing blockchain technology and cryptocurrency namely. Fourth, Payhalal is a sharia fintech in collaboration with banks and non-bank financial institutions in certain payment card provider countries. It provides a payment gateway platform that facilitates global payment transactions subject to sharia principles.

There are some advantages and disadvantages of sharia fintech collecting Ziswaf, at both World and Indonesian levels. First, crowdfunding sharia fintech uses blockchain technology and cryptocurrency. The advantage of using blockchain in fintech is that it can easily detect transaction errors because it is very difficult to change transactions that have been made through blockchain technology (immutable), easy to tracer, and all users (transparent) can monitor all

31 Hazik Mohamed, Hassnian Ali, Blockchain, Fintech, and Islamic Finance: Building the Future in the New Islamic Digital Economy, Boston/Berlin: Walter de Gruyter Inc., 2018, p. 180.

32 Elipses, "The Global Islamic Fintech Report, accessed on December 2019", https://ceif.iba.edu.pk/pdf/IslamicFinTechReport19.pdf, accessed on October 2020.

33 Dubai Islamic Economy Development Centre, "Islamic Fintech Report 2018: Current Landscape \& Path Forward", https://www.dinarstandard.com/wp-content/uploads/2018/12/Islamic-Fintech-Report-2018.pdf, accessed on October 2020.

34 Vineena Tan, "IFN Islamic Fintech", https://ifnfintech.com/ifn-fintech-survey-2020-results/, accessed on October 2020. 
transactions. On the other hand, cryptocurrency is electronic money that can be used to replace fiat currency as a medium of exchange by using blockchain as a guarantee of transaction security. ${ }^{35}$ However, some Muslim scholars disagree the use of cryptocurrency in the Islamic economy. They are, among others, Professor Ahmed Kamel Midin Merra, former Dean of the Institute of Islamic Banking and Finance at the International Islamic University of Malaysia. He says that if cryptocurrency is accepted in the Islamic finance industry, it must have an intrinsic value, and is not a commodity tool. ${ }^{36}$ Another Muslim scholar who rejects cryptocurrency is the great Egyptian mufti, Shaikh Shaki Alam. He openly rejects cryptocurrency on the grounds that it violates sharia principles. Sharia principles are violated due to several reasons. First, there is an element of gharar (uncertainty). Second, the real value of currency is unknown. Third, prices are very volatile. Fourth, it can be easily misused in criminal acts because of their anonymity. Fifth, there are differences in value determination and valuation methods. Sixth, it does not have Central bank supervision. Seventh, cryptocurrency volatility is very high because it can be affected by several factors, some of which are hackers and technical errors. ${ }^{37}$

In Indonesia, the use of cryptocurrency is not permitted in fintech companies that transact in the territory of the Republic of Indonesia. This is stated in Article 44, letter a, of the Regulation of Bank Indonesia Number 20/6/PBI/2018 on Electronic Money in conjunction with Article 2 of the Regulation of Bank Indonesia Number 17/3/PBI/2015 on the Mandatory Use of Rupiah in the Territory of the Republic of Indonesia in conjunction with Article 21 of Law Number 7 of 2011 on Currencies. Electronic money administrators (fintech payments and remittances) must comply with the provisions governing the mandatory use of rupiah for payment transactions made within the territory of the Republic of Indonesia. Sanctions for violating the above regulations are stated in Article 33 paragraph (1) of the Law on Currencies, shall be punished with a maximum imprisonment of 1 (one) year and a maximum fine of Rp200,000,000.00 (two hundred million rupiah). Therefore, cryptocurrency can only be accepted as a medium of exchange in Islam if it can provide certainty in exchange rate stability, protection or guarantee from abuse, operates under sharia financial regulations, and does not violate the laws of a country. ${ }^{38}$

35 Mustafa Raza Rabban, Shahnawaz Khan, Eleftherios I, Thalassinos, "FinTech, Blockchain and Islamic Finance: An Extensive Literature Review", International Journal of Economics and Business Administration, Vol. VIII, Issue 2, 2020, p. 72.

36 Nisar Ahmed, Khadija Rasheed, and Muhammad Talha, "Islamic Banking Perspective on Shariah Compliant FinTech (Financial Technology) Model", Islamic Banking Fintech, 2019, p. 29.

37 Mustafa Reza Rabban, op.cit., p. 75.

38 Ibid. 
Second, fintech payments that use an e-wallet platform is similar to the deposit contract that applies to Islamic banks. In sharia transactions, the deposit contract is divided into two types of contracts, namely wadiah yad amanah and wadiah yad damanah. The first is a contract for safekeeping where the party receiving the deposit is not allowed to use the entrusted item at all. Therefore, the party is not responsible for the risk that occurs in the item deposited in it. Accepting safekeeping is only obliged to return the item deposited when requested by the party depositing it in its original state. The second is a deposit contract that allows parties to receive a deposit to use or take advantage of the item that was deposited. Therefore, the party receiving the safekeeping at the same time who utilizes or uses the deposited item participates in risks such as the risk of damage and loss.

The regulation on wadiah can be found in Article 36, letter a, point 1, of the Regulation of Bank Indonesia Number 6/24/PBI/2004 on Commercial Banks Conducting Business Activities based on Sharia Principles. It states that banks are required to apply sharia principles and prudential principles in their business activities in the form of demand deposits based on the wadiah principle. The Fatwa of the National Sharia Council Number 01/DSN-MUI/IV/2000 states that demand deposits that are justified in sharia are those based on the principles of mudharabah and wadiah. ${ }^{39}$ The general provisions for deposits that are based on the wadiah principle are deposit that can be taken at any time (on call). There should be no additional promised amount for the funds deposited. ${ }^{40}$

Based on the explanation above, fintech payment with an e-wallet platform as a means of collecting Ziswaf to comply with sharia principles can use a wadiah (deposit) contract. Based on Article 48 of the Regulation of Bank Indonesia Number 20/6/PBI/2018 on Electronic Money, fintech float funds be allocated a minimum of $30 \%$ (thirty percent) in commercial bank current accounts and a maximum of $70 \%$ (seven fifty percent) in securities issued by the Government or Bank Indonesia. Therefore, part of the deposited funds must be used or managed by Bank Indonesia. It means that the right contract to be applied to fintech e-wallet is not using the wadiah yad amanah contract but the wadiah yad dhamanah contract. Therefore, the funds deposited can be used to be invested. However, what is being considered is that these funds are invested in securities issued by the Government or Bank Indonesia in the form of bonds, so that the recipient of the bonds (fintech companies) receives returns in the form of interest (usury) on a regular basis. Therefore, the bonus given, even though it was not previously agreed, still contains usury.

The formation of special rules for sharia fintech in Indonesia is very urgent. The 2018 Islamic fintech Report states that Indonesia has largest Islamic fintech owner

\footnotetext{
39 Abdul Ghofur Anshori, Hukum Perbankan Syariah di Indonesia, Yogyakarta: Gadjah Mada University Press, 2018, p. 83.

$40 \quad$ lbid, p. 91.
} 
in the world, above the United States and the United Arab Emirates. ${ }^{41}$ However, there are no rules on sharia fintech in Indonesia. In determining the quality of the formation of sharia fintech law, several researchers conclude that there are four factors that must be emphasized. They are (1) sharia advisory board, (2) sharia management, (3) sharia implementation, and (4) compliance and improvement. ${ }^{42}$

This study tries to provide an analysis of the concept of sharia financial institution regulation that already exists in Indonesia to be able to fulfill the four factors above. First, the Sharia Advisory Board is an institution that is authorized to supervise, regulate, and provide advice on Islamic financial transactions in Indonesia. It was officially established in 1999 based on Decree of the MUI Number Kep-754/MUI/II/1999 on the Establishment of the MUI's National Sharia Council. This authority rests with the Sharia Supervisory Board (DPS) and the National Sharia Council of the Indonesian Ulema Council (DSN MUI) as sharia institutions that are tasked to oversee the operational activities of Sharia Financial Institutions. DSN members consist of practitioners in the field of sharia economics, scholars, and experts in fields related to muamalah. Based on the Decree of the DSN MUI Number 1 of 2000 on the Basic Guidelines for the National Sharia Council, the duties and authorities of the DSN include fostering sharia values, providing fatwas on types of financial activities, issuing fatwas on sharia financial products and services, overseeing the implementation of fatwas that have been published. ${ }^{43}$

DSN has some authorities. First, they issue fatwa that binds the DPS in every Islamic financial institution (LKS). Second, they recommend and/or revoke the recommendation of a DPS candidate on an LKS. Third, they give a warning to the LKS on against deviations from the issued fatwa. Fourth, they provide suggestions to the competent agency to take action if warnings of disregard. Fifth, they validate draft of fatwa. Sixth, they hold plenary meetings and make annual reports on LKS that do not comply with all Sharia provisions objected by the DSN MUI. ${ }^{44}$

DPS is a Sharia Supervisory Board placed at the head office to function as a supervisor, mediator between LKS and DSN, providing advice and suggestion to the head of the Sharia Business Unit and the head of the sharia branch office regarding aspects of sharia. The duties and functions of DPS are regulated more clearly in Article 27 of the Regulation of Bank Indonesia Number 6/24/PBI/2004 on Commercial Banks Conducting Business Activities Based on Sharia Principles. Violations of compliance with sharia principles will be subject to administrative sanctions as stated in Article 56 of Law Number 21 of 2008 on Islamic Banking. Currently the authority of DSN and DPS only applies to Islamic financial institutions,

\footnotetext{
Dubai Islamic Economy Development Centre, op.cit

Nisar Ahmed, op.cit., p. 16.

Abdul Ghofur, op.cit., pp. 44-48.

Ibid.
} 
such as sharia banks and sharia non-bank financial institutions (IKNB), for example the capital market, financing, and insurance. It does not yet cover fintech because fintech is generally categorized as digital financial services (specifically for payment providers) in Indonesian law. Article 1 of the Regulation of Bank Indonesia on Electronic Money says no specific regulation regarding the separation of conventional and sharia fintech operations. DPS and DSN can carry out their function as sharia advisory bodies in sharia fintech but all that is needed is strict rules.

The second is related to management, implementation, and compliance. Indonesia has compiled sharia economic law in the Book of Sharia Economic Law (KHES) based on Regulation of the Supreme Court of the Republic of Indonesia Number 2 of 2008 on the Compilation of Sharia Economic Law (KHES). It is the result of ijtihad carried out collectively by Indonesian scholars as well as a number of regulations and circulars issued to accommodate the fatwas of the DSN MUI. ${ }^{45}$ KHES does not bind in nature. However, judges use it as material legal material to decide sharia economic legal disputes, based on Article 55 of the Law Number 21 of 2008 on Islamic Banking in conjunction with Article 49 of the Law Number 3 of 2006 on Religious Courts. In essence, the laws states that the settlement of disputes in the field of sharia economics includes micro sharia financial institutions and sharia banking are carried out by courts within the religious court environment. In addition, it can also be resolved on the non-litigation path as long as it complies with sharia principles (Article 49 paragraph (2) and (3) of the Sharia Banking Law). The DSN MUI fatwas regarding muamalah are clear and can be implemented in sharia fintech. In the event of a dispute, the religious court has the authority to decide by litigation and Basyarnas on a non-litigation basis with reference to KHES.

The fintech platform in collaboration with Baznas should be designed to comply with sharia principles. However, the establishment of fintech is still regulated by general regulations that do not apply sharia principles in its business transactions. It is the duty of the OJK and $\mathrm{BI}$ to specifically regulate sharia fintech, including the form of transactions \& sharia contract mechanisms, its supervision, dispute settlement, and protection, even though it is a common thing that technology develops faster than law; and law cannot develop technological changes. ${ }^{46}$

Considering some of these fintech activities still carry out business activities that contain elements of usury, Baznas is obliged to make clear agreements with fintech parties. They include:

(1) separating the Ziswaf funds collected so that they do not get mixed up with funds deposited by other parties;

45 Andri Soemitro, Hukum Ekonomi Syariah dan Fiqh Muamalah di Lembaga Keuangan dan Bisnis Kontemporer, Jakarta: Prenada Media, 2019, p. 3.

46 Susanne Chishti, Sophia Adams Bhatti, Akber Datoo, Drago Indjic, The LegalTech Book: The Legal Technology Handbook for Investors, Entrepreneurs and FinTech Visionaries, UK: TJ international Ltd., 2020, p. 60. 
(2) ziswaf funds are not considered as float funds as defined in the Regulation of Bank Indonesia on electronic money;

(3) in order to avoid the elements of riba, gharar, and haram, neither Baznas, muzakki, nor mustahik may take advantage of bonuses, vouchers or lotteries from Ziswaf fund deposits; and

(4) as well as prohibiting fintech from investing Ziswaf funds that have settled with transactions that are not halal.

The principle of zakat payment, it is immediate (fauriyyah), not deferred (alTarakhi). Therefore, delaying the payment of zakat is not allowed, even for the purpose of investment. Article 7 of Law Number 23 of 2011 on Zakat Management allows Baznas to utilize zakat for productive endeavors but the utilization of zakat can only be carried out if the basic needs of the mustahik have been met. According to Al-Masyiqah, ${ }^{47}$ zakat investment is to look for profit by doing business with zakat assets in three ways as follows.

(1) Zakat investment can be made by people who give the zakat, or muzzaki.

(2) Zakat property investments can be made by zakat recipients, or mustahiq.

(3) Zakat investment can be made by OPZ.

The benefits of zakat investment are intended for the zakat recipients in the short and long term while still adhering to the principles of sharia. Thus, Ziswaf utilization can only be carried out by fintechs operating under sharia principles through a profit-sharing ratio agreement.

\section{E. The Role of Mosques in the Utilization of Sharia Fintech to Optimize Ziswaf Collection and Distribution}

As previously explained, mosques, mushala, and surau can be part of the Zakat Management Organization (OPZ) in the form of a Zakat Management Unit (UPZ) formed by the district or city Baznas with written notification to the Head of the District Office of Religious Affairs (KUA). On the collaboration between Baznas and fintech, so far, ziswaf funds collected by Fintech are transferred to the Central Baznas account. The Central Baznas then distributed the funds to every LAZ and UPZ. However, based on several hadiths regarding the collection of zakat fitrah in the month of Ramadan, muzakki are required to pay zakat in the place where the muzakki is domiciled. This is according to the hadith of the Prophet Muhammad (PBUH) when sending Mu'adz bin Jabal to Yemen, the Prophet (PBUH) says,

47 Al-Masyiqah, Khalid Bin Ali, Fikih Zakat Kontemporer, Yogyakarta: Samudra IImu, 2007, p. 105. 
"If they obey me, then teach them that Allah SWT requires zakat on them in their property. It must be taken from those who are capable among them and handed over to those who are poor among them." 48

Furthermore, according to the Shafi'i School, it is not permissible to transfer zakat from one region to another. The zakat must be distributed to the place where it is collected. Zakat can only be transferred to another place if there is no mustahik in that place. ${ }^{49}$

Based on the hadith above, the function of mosques spread across Indonesia is to collect and distribute zakat fitrah at the muzakki's domicile. The zakat fitrah must be right on target and addressed to mustahik who are in the same location. This study offers a solution so that each mosque has an account that is registered with sharia fintech to collect Ziswaf, especially zakat fitrah. Therefore, the muzakki can choose to pay at the muzakki's domicile mosque. The system is peer-to-peer Ziswaf payments between muzakki and the mosque in the muzakki's domicile. In addition, the role of the mosque is also to provide literacy and socialization to the community around the mosque to download Islamic fintech so that distribution can be carried out efficiently and effectively. This will provide many benefits, including increasing the accountability of the mosque's financial statements, increasing the role of mosques in preserving the surrounding community, popularizing the use of sharia fintech in the midst of society, and indirectly increasing Islamic financial inclusion. This can only be done by mosques because mosques have received permission from Baznas to collect, distribute, and manage ziswaf as an UPZ. This is clearly stated in the Zakat Law, that is, every person, whether a legal entity or an individual, is prohibited from doing or acting as amil zakat without permission from the authorized official. For those who violate, according to Article 41 of the Zakat Law, they are punished with imprisonment of a maximum of one year and/or a maximum fine of fifty million rupiah.

\section{F. Conclusion}

The use of fintech in digitizing Ziswaf mosques is a solution for OPZ parties to optimize mosques' Ziswaf in the Covid-19 pandemic era. However, fintech in collaboration with Baznas is still a subject to general rules. The fintech operations still contain elements of usury such as receiving interest from bonds issued by the Government or Bank Indonesia on float funds and elements of gharar or maisir in lottery transactions. Sharia fintech is a solution in the management, collection, and utilization of Ziswaf in order to avoid things that are against the principles of sharia.

\section{References}

48 Syekh 'Athiyyah Shaqar, Syekh Dr. Yusuf Al-Qaradhawi, Syekh DR. Ali Jum'ah, 30 Fatwa Seputar Ramadhan, Pekanbaru: Zanafa, 2018, p. 65.

49 Ibid. 


\section{Books}

Abdul Ghofur Anshori, Hukum Perbankan Syariah di Indonesia, Gadjah Mada University Press, Yogyakarta, 2018.

Alam, Nafis, Lokesh Gupta, Abdolhossein Zameni, Fintech and Islamic Finance: Digitalization, Development and Disruption, Springer Nature, Switzerland, 2019.

Al-Masyiqah, Khalid Bin Ali, Fikih Zakat Kontemporer, Samudra IImu, Yogyakarta, 2007.

Andri Soemitro, Hukum Ekonomi Syariah dan Fiqh Muamalah di Lembaga Keuangan dan Bisnis Kontemporer, Prenada Media, Jakarta, 2019.

Chishti, Susanne, Sophia Adams Bhatti, Akber Datoo, Drago Indjic, The LegalTech Book: The Legal Technology Handbook for Investors, Entrepreneurs and FinTech Visionaries, TJ international Ltd., UK, 2020.

Departemen Pengembangan Akses Keuangan and UMKM Bank Indonesia, Booklet Keuangan Inklusif, Bank Indonesia, Jakarta, 2014.

Freedman, Roy S, Introduction to Financial Technology, Academic Press, United States, 2006.

Hammad, Nazih, Al-Uqud Al-Murakkabah fi Al-Fiqh Al-Islamiy, Dar al-Qalam, Damaskus, 2005.

Mohamed, Hazik, Hassnian Ali, Blockchain, Fintech, and Islamic Finance: Building the Future in the New Islamic Digital Economy, Walter de Gruyter Inc., Boston/Berlin, 2018.

Pusat Kajian Strategis Badan Amil Zakat Nasional, Outlook Zakat Indonesia 2020, Pusat Kajian Strategis - Badan Amil Zakat Nasional (PUSKAS BAZNAS), Jakarta, 2020.

Rudi Hermawan, Buku Ajar Hukum Ekonomi Islam, Duta Media Publishing, Pamekasan, 2017.

Syekh 'Athiyyah Shaqar, Syekh Dr. Yusuf Al-Qaradhawi, Syekh DR. Ali Jum'ah, 30 Fatwa Seputar Ramadhan, Zanafa, Pekanbaru, 2018.

\section{Other Documents}

Ahmad Syahid, "Go-Food dalam Tinjauan Cendekiawan Muslim", FINANSIA: Jurnal Akuntansi dan Perbankan Syariah, Vol. 1, No. 1, 2018.

Ahmed, Nisar, Khadija Rasheed, and Muhammad Talha, "Islamic Banking Perspective on Shariah Compliant FinTech (Financial Technology) Model", Islamic Banking Fintech, 2019.

Arner, Douglas W., Janos Nathan Barberis, and Ross P. Buckley, "The Evolution of Fintech: A New Post-Crisis Paradigm?", University of New South Wales Law Research Series.

Ascarya and Diana Yumanita, "Analisis Rendahnya Pengumpulan Zakat di Indonesia dan Alternatif Solusinya", Working Paper Bank Indonesia, No. 9, 2018. 
Badan Amil Zakat Nasional, "BAZNAS Ajak Masyarakat Zakat Digital", https://baznas.go.id/Press_Release/baca/BAZNAS_Ajak_Masyarakat_Zakat_Dig ital/531.

"Laporan Statistik Badan Amil Zakat Nasional Tahun 2019", https://baznas.go.id/szn/2019.

Dubai Islamic Economy Development Centre, "Islamic Fintech Report 2018: Current Landscape \& Path Forward", https://www.dinarstandard.com/wpcontent/uploads/2018/12/Islamic-Fintech-Report-2018.pdf.

Dzulqorinain bin Muhammad Sunus, "Beberapa Hukum Berkaitan dengan Undian", https://darussalaf.or.id/beberapa-hukum-berkaitan-dengan-undian/.

Eldo Christoffel Rafael, "Alvara Research Center: Go-Jek jadi Terfavorit di Kalangan Milenial", https://industri.kontan.co.id/news/alvara-research-center-go-jekjadi-terfavorit-di-kalangan-milenial.

Elipses, "The Global Islamic Fintech Report, December 2019", https://ceif.iba.edu.pk/pdf/IslamicFinTechReport19.pdf.

Evi Steelyana W, "Perempuan dan Perbankan: Sebuah Tinjauan tentang Inklusi Keuangan terhadap Pengusaha UMKM Perempuan di Indonesia (Woman and Banking: A Review of the Role of Financial Inclusion on Woman SME Enterpreuners in Indonesia)", Economics, Business and Information System Journals, Vol. 14, No. 2, 2013.

Firdos Nofrison, "Studi Analisis terhadap Fatwa Dewan Fatwa Perhimpunan AlIrsyad No: 005/Dfpa/Vi/1439 tentang Haramnya Diskon yang Didapatkan dari Go-Pay dan Layanan yang Sejenisnya", Skripsi, UIN Suska Riau, 2019.

Gulamhuseinwala, Imran, Thomas Bull, and Steven Lewis, "Fintech is Gaining Traction and Young, High-Income Users are the Early Adopters", Journal Of Financial Perspectives, Vol. 3, Issue 3, 2015.

Muhammad Abdul Wahab, Lc, "Benarkah Go-Food Haram?", https://www.rumahfiqih.com/.

Otoritas Jasa Keuangan, "7 Inisiatif Strategis OJK untuk Pertumbuhan dan Pemerataan Ekonomi", https://www.ojk.go.id/id/berita-dan-kegiatan. "Siaran Pers Survei OJK 2019 tentang Indeks Literasi dan Inklusi Keuangan Meningkat, https://www.ojk.go.id/id/berita.

Rabban, Mustafa Raza, Shahnawaz Khan, and Eleftherios I, Thalassinos, "FinTech, Blockchain and Islamic Finance: An Extensive Literature Review", International Journal of Economics and Business Administration, Vol. VIII, Issue 2, 2020.

Saksonova, Svetlana, and Irina Kuzmina-Merlino, "Fintech as Financial Innovation The Possibilities and Problems of Implementation", European Research Studies Journal, Volume XX, Issue 3A, 2017.

Simpanan Online Sahabatku, "Aturan Umum Pengguna Sobatku", https://www.sobatku.co.id/aturan-jadwal-undian-sobatku.

Tan, Vineena, "IFN Islamic Fintech", https://ifnfintech.com/ifn-fintech-survey-2020results/. 
World Population "2020 Weview, World Population", https://worldpopulationreview.com/.

\section{Legal Documents}

Law Number 23 of 2011 on Zakat Management in Indonesia [Undang-undang Nomor 23 Tahun 2011 tentang Pengelolaan Zakat di Indonesia].

Law Number 24 of 2004 on the Deposit Insurance Agency [Undang-undang Nomor 24 tahun 2004 tentang Lembaga Penjamin Simpanan].

Law Number 7 of 2011 on Currency [Undang-undang Nomor 7 Tahun 2011 tentang Mata Uang].

Law Number 21 of 2008 on Islamic Banking [Undang-undang Nomor 21 Tahun 2008 tentang Perbankan Syariah].

Government Regulation Number 14 of 2014 on the Implementation of the Law Number 23 of 2011 on the Management of Zakat [Peraturan Pemerintah Republik Indonesia Nomor 14 Tahun 2014 tentang Pelaksanaan Undangundang Nomor 23 Tahun 2011 tentang Pengelolaan Zakat].

Regulation of Bank Indonesia Number 18/40/PBI/2016 on the Implementation of Payment Transaction Processing [Peraturan Bank Indonesia Nomor 18/40/PBI/2016 tentang Penyelenggaraan Pemrosesan Transaksi Pembayaran].

Circular of Bank Indonesia Number 18/22/DKSP on the Implementation of Digital Financial Services [Surat Edaran Bank Indonesia Nomor 18/22/DKSP perihal Penyelenggaraan Layanan Keuangan Digital].

Regulation of Bank Indonesia Number 20/06/PBI/2018 on Electronic Money [Peraturan Bank Indonesia Nomor 20/06/PBI/2018 tentang Uang Elektronik].

Regulation of Bank Indonesia Number 17/3/PBI/2015 on the Mandatory Use of Rupiah in the Territory of the Republic of Indonesia [Peraturan Bank Indonesia Nomor 17/3/PBI/2015 tentang Kewajiban Penggunaan Rupiah di Wilayah Negara Kesatuan Republik Indonesia].

Regulation of Bank Indonesia Number 6/24/PBI/2004 on Commercial Banks Conducting Business Activities based on Sharia Principles [Peraturan Bank Indonesia Nomor 6/24/PBI/2004 tentang Bank Umum yang Melaksanakan Kegiatan Usaha berdasarkan Prinsip Syariah].

Regulation of the Financial Services Authority of the Republic of Indonesia Number 77/POJK.01/2016 on Information Technology-Based Lending and Borrowing Services [Peraturan Otoritas Jasa Keuangan Republik Indonesia Nomor 77/POJK.01/2016 tentang Layanan Pinjam Meminjam Uang Berbasis Teknologi Informasi].

Regulation of the Financial Services Authority of the Republic of Indonesia Number 13 /Pojk.02/2018 on Digital Financial Innovation in the Financial Services Sector 
[Peraturan Otoritas Jasa Keuangan Republik Indonesia Nomor 13/Pojk.02/2018 tentang Inovasi Keuangan Digital di Sektor Jasa Keuangan].

Fatwa of the National Sharia Council Number 01/DSN-MUI/IV/2000 on Giro [Fatwa Dewan Syariah Nasional Nomor 01 /DSN-MUI/IV/2000 tentang Giro].

Decree of the Indonesian Ulema Council Number Kep-754/MUI/II/1999 on the Establishment of the MUI National Sharia Council [Surat Keputusan Majelis Ulama Indonesia Nomor Kep-754/MUI/II/1999 tentang Pembentukan Dewan Syari'ah Nasional MUI].

Decree of the National Sharia Council of Indonesian Ulema Council Number 1 of 2000 on Basic Guidelines for the National Sharia Council [Surat Keputusan DSN MUI Nomor 1 Tahun 2000 tentang Pedoman Dasar Dewan Syariah Nasional]. 